\title{
Aldames Language: Its Landscapes and Topographies
}

\author{
Leo H. Aberion, Ph.D. ${ }^{1} \&$ Luzviminda S. Roda, $\mathrm{MBA}^{2}$ \\ ${ }^{1}$ Department of Languages and Literature, College of Arts and Sciences, University of San Jose-Recoletos, Cebu \\ City, Cebu, Philippines \\ ${ }^{2}$ Department of Social Sciences and Philosophy, College of Arts and Sciences, University of San Jose-Recoletos, \\ Cebu City, Cebu, Philippines \\ Correspondence: Leo H. Aberion, Ph.D, Department of Languages and Literature, College of Arts and Sciences, \\ University of San Jose-Recoletos, Cebu City, Cebu, Philippines
}

Received: November 14, 2017

Accepted: June 11, 2018

Online Published: June 14, 2018

doi:10.5430/elr.v7n2p20

URL: https://doi.org/10.5430/elr.v7n2p20

\begin{abstract}
The Philippines is composed of almost 200 languages and dialects, more or less, and eight (8) of these are considered major languages, namely: Bikolano, Cebuano, Hiligaynon (Ilonggo), Ilocano, Kapampangan, Pangasinan, Tagalog, and Waray. However, there are still varied languages which are not yet recognized, and one of these is Aldames, a variety of the Cebuano language. The purpose of this study was to determine the origin, the characteristics, and the unique features of the Aldames language. This study used the qualitative approach in which the data were gathered through actual interviews and conversations from the speech community. Recorded interviews and conversations were then transcribed and categorized into themes. It was found out that the "Aldames" language is a modified version of the English alphabet because the language has corresponding letters in English. However, changes occur in most consonants (b/v-m, c/k-n, d-p, f.p-d, g/ng-r, k/c-n, l-1l/ly, m-b, n-k/c, p-d, q/kyu-nyu, r-g/ng, s-t, y/eks-ent, $\mathrm{z} / \mathrm{s}-\mathrm{t}$ ) while all vowels $(\mathrm{a}, \mathrm{e}, \mathrm{i}, \mathrm{o}, \mathrm{u})$ and few consonants (h, w, and $\mathrm{y}$ ) are retained except for " $\mathrm{j}$ " which has no Aldames equivalent. Also, it emerged because the elders would not want their secrets to be revealed by the young and would only be understood by a few. Hence, today, the residents who are not exposed to the language in the area are confused in learning the language because before one can speak well, he/she should be familiar with the appropriate consonants-substitutes. It is recommended that the language must be recognized and be included in the list of languages in the Philippines. Moreover, the said language has to be spoken every day, so it will be preserved.
\end{abstract}

Keywords: language, topographies, landscapes, linguistic features, Aldames, Cebuano-Visayan

\section{Introduction}

The language of the Philippines was originally written in the Baybayin script, which in turn is similar to those used in Java, Bali, and Sumatra. Today, the Latin alphabet has replaced the previous one and is the means by which most Filipinos write Tagalog, the common name for the national language of the Philippines, although not exactly the same since Filipino is a variant of Tagalog. In the Philippines, due to a history of multiple settlements, more than 170 languages are spoken and only 2 of them are official in the country: Filipino (the national language) and English (Bernas, 1996). With very little written output, not much is known about this language for the history prior to the arrival of the Spanish during the sixteenth century (Scott, 2011).

Aside from Filipino as the national language, English is the dominant language in business, government, the legal system, medicine, and education. Filipinos would prefer much to have their text books written in English rather than in Filipino because it is much easier to comprehend and is much more useful in the "real world especially to communicate with foreigners. At home, however, most speak in their dialects (mother tongue). English brings along with it a sense of formality and almost everyone can understand the language. Even in the most remote areas of the Philippines, the elder generation of people can still understand English (Steinberg, 1982).

With the variety of languages and dialects in the Philippines, Tagalog is widely spoken in the Philippines. The national language, Filipino, is derived from Tagalog, and its alphabet has five vowels and fifteen consonants. The Tagalog alphabet is made up of syllables, where each consonant has an inherent vowel /a/. Other vowels are indicated by different letters separately or through dashes. A dash over a consonant turns the vowel into /i/ or /e/, while a dash below transforms it into $/ \mathrm{o} / \mathrm{or} / \mathrm{u} /$. The language is written from left to right horizontally. This is important information for the 
world of translation, either to analyze a work originally written in Tagalog or to know how to deliver a translation into that language (Philippines History Index, 2001).

One of the major regional languages in the Philippines is Cebuano, a variety of the Visayan languages (Cebuano-Visayan). The Cebuano-Visayan language may be the strongest language next to Tagalog, with its number of speakers, many advocacy groups advancing its use and the usage of the language by its speakers. Today, it already reaches to the capital city of the Philippines and a language to be considered in code switching. However, this language is still faced with problems, so several studies are conducted to determine the Cebuano-Visayan language varieties.

In Bohol, a neighboring island of Cebu, Cebuano-Visayan language has a strong hold on the population for majority of the people there are originally Cebuano or migrants from Cebuano-speaking areas. It also has a prominent university-the University of Bohol-which houses studies on the Cebuano language. There are also many cultural organizations focused on preserving the heritage of Bohol and its language.

In Davao which is a part of the Mindanao islands, almost $80 \%$ of the population are Cebuanos. Davao became a Cebuano-Visayan-speaking area because of the migration of the people, which happened full-scale in the 1930's. During the Spanish period, Tagalog was the lingua franca of Davao because it was where the dregs of Luzon society were thrown, together with other people from the Visayas and the soldiers. It was already a melting pot of cultures which remains until today. Davao is a metropolitan region which is one of the developed areas in Mindanao. Cebuano-Davao faces threat from Tagalog. There are many people, especially those in the urban areas who use Tagalog as their medium of communication, even students in their classes. But this scenario is found only in the cities. In rural areas, Cebuano-Visayan is still the language for everybody. Although Tagalog had remained in Davao, there is strength in numbers; therefore, Cebuano-Visayan remains as the majority language (Bisaya.com).

Unlike Davao, Cebu was not a settlement area but still, Tagalog has been gaining a stronghold. This is mostly due to the mass media and the language used in schools as a medium of instruction especially in Filipino and Social Studies courses. As the years go by, Cebuanos saw their numbers dwindle and the people are being stereotyped in the media as the 'Indays' and 'Dodongs', servants, low-class people who are often the subject of comedy and mockery. They are distinguished by pronouncing the Tagalog/English ' $\mathrm{e}$ ' as [I] or [i], and the ' $\mathrm{o}$ ' as [ $\mathrm{v}]$ or [u]. This may be true for some, but in shows, this characteristic is often exaggerated. Many groups reacted to one movie entitled 'Sakal, Sakali, Sakalo' wherein Gloria Diaz, the grandmother, told her maid Ba't mo pinalaking Bisaya ang apo ko? 'Why did you rear my grandson as Bisaya? (can be equivalent to Cebuano), to which Judy Ann Santos, the mother adds, Dapat Tagalog para Pinoy 'It should be Tagalog to be Filipino.' Following this paradigm, then, more or less $70 \%$ of the Philippine population are not Filipinos because they are not Tagalog native speakers or even second language speakers (Endriga, 2010).

With respect to the other official language, English traces its roots in the Philippines to colonization. The United States colonized the Philippines from 1898 to 1946. Just as the Spanish learned to leave its mark, English also seeped into the language, food, movies, and sports of the country. However, movements were formed to protect the Filipino language, from professional writers to enthusiasts, who are interested in preserving the language as well as the culture and identity of its speakers (National Geographic, 2017).

In the southern part of Cebu, particularly Barngay Bato (officially known as San Sebastian) which belongs to the municipality/town of Samboan, some folks in this barangay spoke and still speak a sort of a special language. It is a variation of the Cebuano-Visayan language popularly known in the community as "Aldames". It is derived from the term Alphabet (Alpabet - Aldames). Maria "Mary" Ferrater-Singco, who is currently 79 years old (as of 2017), narrated that in 1947, when she was about 10 years old, she heard and started speaking the language that she learned from her mentors. She could not tell when it actually started, but she believed it really started long before she heard it spoken. She handed it to her children to the grandchildren and now, even to her great grandchildren. Some of her children are currently living abroad, but they are still fluent in speaking Aldames. The Aldames language just came out naturally from their tongue once a person initiates to speak the said language.

Those who were born in Bato (San Sebastian), and were able to speak the Aldames language since birth, are still communicating the same language even in social media like Facebook, Instagram, twitter, among others, and they are still fluent is speaking the language. In the Cebuano Studies Center of the University of San Carlos, Cebu City, Cebu, Philippines, the language has not been registered as one of the languages spoken in the province of Cebu. With this, the study is conducted, to study on the origin/roots and features of the Aldames language as a variety of the Cebuano-Visayan language. 


\section{Methodology}

This study aimed to answer the following questions.

1. What is the profile of the speakers of Aldames language?

2. What is the origin of the Aldames language?

3. What are the characteristics of Aldames language?

4. What are the unique features which are different from the Cebuano-Visayan language?

5. What do the speakers do to preserve the language?

This study utilized the qualitative approach in analyzing data. There were six participants of the study who allowed themselves to be interviewed. They were chosen because they are exposed in speaking Aldames language every day. They were asked using the Aldames language, and they responded on the same language purely and completely. Interviews were then recorded and transcribed. From the data, themes were created and segregated to answer the questions on the roots/origin and characteristics of the Aldames language. After the transcription from the Aldames language, the utterances/information gathered were translated to Cebuano and English.

The interview was limited only to six (6) participants/respondents because they are the immediate descendants of those long time speakers of the "Aldames" language who passed away, and these respondents were able to acquire and to be taught by their parents or grandparents. To respect the identity of the speakers and the confidentiality carried on in this study, each speaker was assigned with a code.

\section{Results}

\subsection{Profile of the Current Speakers according to Age}

There were seven (7) native speakers (represented by letters in the upper case) of Aldames who passed away. Speaker A died at the age of 96; Speaker B died at the age of 95; Speaker C died at the age of 83; Speakers D and E died at the age of 82; Speaker F died at the age of 80; and Speaker G died at the age of 75.

There were a total of 15 descendants (represented by letters in the lower case) who are still alive and still living in the place (Bato, Samboan, Cebu, Philippines). Speaker (a) is 85 years old; Speaker (b) is 82 years old; Speaker (c) is 79 years old; Speakers (d) and (e) are 62 years old; Speakers (f) and (g) are 60 years old; Speaker (h) is 53 years old; Speaker (i) is 52 years old; Speaker (j) is 51 years old; Speakers (k) and (l) are 48 years old; Speaker (m) is 15 years old; and Speaker (n) is 13 years old. However, the siblings, friends, and relatives of these speakers can also speak and understand the Aldames language even though they are already living in other islands within or outside the Philippines.

The participants'/respondents' profile (represented by Arabic numerals) are the following: Speaker 1 is 35 years old; Speaker 2 is 48 years old; Speaker 3 is 79 years old; Speaker 4 is 54 years old; Speaker 5 is 49 years old; and Speaker 6 is 58 years old.

It is very important and significant to determine the speakers' age to establish the length of time when they learned and spoke the Aldames language. Also, this is to determine the existence of the Aldames language in the Philippines, particularly in Bato, Samboan, Cebu. Moreover, it is relevant to include those speakers who passed away because their family members are still alive who continue to speak the Aldames language, so the said language is carried on from generation to generation. Based on the account of the participants, Speakers A and B who died at ages 95 and 96, respectively, were dead for over a decade already (since 2017) and before they died, they still spoke the Aldames language.

\subsection{Origin of the Language}

There is no specific identification or description as regards the origin of the Aldames language because most of the speakers were speaking the said language since birth. They were told that the Aldames language was used to conceal or keep secrets especially to the younger children and most especially to the visitors who were only familiar in speaking the Cebuano-Visayan language (the first language of all native speakers of Aldames language). The Aldames language was anchored on the first language of the speakers which is Cebuano-Visayan. Using the English alphabet from $\mathrm{A} / \mathrm{a}$ to $\mathrm{Z} / \mathrm{Z}$, the Aldames language was translated from a Cebuano-Visayan term since Cebuano-Visayan uses the same letters in English except for letter $\mathrm{J} / \mathrm{j}$ which has no Aldames equivalent.

When the respondents were asked regarding the origin or source of the Aldames language, they responded. 
Speaker 1: Ta bakra sawo ta abor mallay ur ta bakra tillikrak. Bakra abira dop. (From the people in the house and from my neighbors. From my friends, too.);

Speaker 2: $\quad$ Ta aboa ga payok ta bakra naumak ta sagamaho. (From our house and from my colleagues.);

Speaker 3: $\quad$ Tauka, illa ki rirabis agok pilli banatamos ar bara masa nok kaay etsogyahak kra daga bara sirulllar. (Yes, when I was still a child, 10 years old, I heard the elders are speaking aldames.);

Speaker 4: "Bao ryup. Piha maya no nahimallo aldames akar ador aduhak kra kabasay." Yes, you're correct. I learned to speak aldames from my grandmother who passed away.);

Speaker 5: "Ta anor baba ur dada ur anor aduhak." (From my mother and my father and my grandmother.)

Speaker 6: "Puray ka oy. Masa da no banatulsi ka no ur rabay kra aldames.” (Long time ago. When I was still a child, I used to speak the aldames a little.)

The respondents mostly acquired and learned the Aldames language from their parents and grandparents. Aside from that, some of them learned Aldames language from their neighbors and friends as emphasized by Speakers 1 and 2.

\subsection{Characteristics of the Language}

Upon scrutiny, the Aldames language has the following characteristics from the Cebuano-Visayan language. Though, it can have a different version of a certain language, but Aldames is generally anchored on the generally spoken language, the Cebuano-Visayan language. Aldames is derived from the term Alphabet. The unique features of the Aldames language is based on letters. The letters in the Aldames language is presented in Table 1.

Table 1. Comparison between the English/Cebuano Alphabet and Aldames

\begin{tabular}{l|l|l}
\hline CEBUANO-VISAYAN ALPHABET/ALPABET & ALDAMES & Similarities/Differences \\
\hline $\mathrm{A} / \mathrm{a}$ & $\mathrm{A} / \mathrm{a}$ & similar \\
$\mathrm{B} / \mathrm{b}$ or $\mathrm{V} / \mathrm{v}$ & $\mathrm{M} / \mathrm{m}$ & different \\
$\mathrm{C} / \mathrm{c}$ or K/k & $\mathrm{N} / \mathrm{n}$ & different \\
$\mathrm{D} / \mathrm{d}$ & $\mathrm{P} / \mathrm{p}$ & different \\
$\mathrm{E} / \mathrm{e}$ & $\mathrm{E} / \mathrm{e}$ & similar \\
$\mathrm{F} / \mathrm{f}$ or P/p & $\mathrm{D} / \mathrm{d}$ & different \\
$\mathrm{G} / \mathrm{g}$ or $\mathrm{NG} / \mathrm{ng}$ & $\mathrm{R} / \mathrm{r}$ & different \\
$\mathrm{H} / \mathrm{h}$ & $\mathrm{H} / \mathrm{h}$ & similar \\
$\mathrm{I} / \mathrm{i}$ & $\mathrm{I} / \mathrm{i}$ & similar \\
$\mathrm{J} / \mathrm{j}$ & & no equivalent \\
$\mathrm{K} / \mathrm{k}$ or $\mathrm{C} / \mathrm{c}$ & $\mathrm{N} / \mathrm{n}$ & different \\
$\mathrm{L} / \mathrm{l}$ & $\mathrm{LL} / \mathrm{ll}$ or LY/ly & similar or with "Y/y" \\
$\mathrm{M} / \mathrm{m}$ & $\mathrm{B} / \mathrm{b}$ & different \\
$\mathrm{N} / \mathrm{n}$ & $\mathrm{K} / \mathrm{k}$ or C/c & different \\
$\mathrm{O} / \mathrm{o}$ & $\mathrm{O} / \mathrm{o}$ & similar \\
$\mathrm{P} / \mathrm{p}$ & $\mathrm{D} / \mathrm{d}$ & different \\
$\mathrm{Q} / \mathrm{q}$ or KYU/kyu & $\mathrm{NYU} / \mathrm{nyu}$ & different \\
$\mathrm{R} / \mathrm{r}$ & $\mathrm{G} / \mathrm{g}$ or NG/ng & different \\
$\mathrm{S} / \mathrm{s}$ & $\mathrm{T} / \mathrm{t}$ & different \\
$\mathrm{T} / \mathrm{t}$ & $\mathrm{Z} / \mathrm{z}$ or S/s & different \\
$\mathrm{U} / \mathrm{u}$ & $\mathrm{U} / \mathrm{u}$ & similar \\
$\mathrm{V} / \mathrm{v}$ or B/b & $\mathrm{M} / \mathrm{m}$ & different \\
$\mathrm{W} / \mathrm{w}$ & $\mathrm{W} / \mathrm{w}$ & similar \\
$\mathrm{X} / \mathrm{x}$ or EKS/eks & $\mathrm{ENT} / \mathrm{ent}$ & different \\
$\mathrm{Y} / \mathrm{y}$ & $\mathrm{Y} / \mathrm{y}$ & similar \\
$\mathrm{Z} / \mathrm{z}$ or $\mathrm{S} / \mathrm{s}$ & $\mathrm{T} / \mathrm{t}$ & different \\
\hline & &
\end{tabular}




\subsection{Unique Features of Aldames Language from Cebuano-Visayan Language}

There is no Cebuano-Visayan Version that is unique from any other languages because Aldames Version is based on the letter/s used and not on the word. However, there are letters with double version especially in the Aldames language. The Aldames language is focused on the letters and not on the sounds or syllables. For example, the letter "B/b" which has a bilabial stop sound in the English or Cebuano-Visayan language, but in the Aldames language, its equivalent is " $\mathrm{M} / \mathrm{m}$ " which has a nasal stop sound. Another example is the letter "G/g" which has a velar stop sound in the English or Cebuano language, but it has a corresponding " $\mathrm{R} / \mathrm{r}$ " with a retroflex stop sound in the Aldames language. There are features like "L/l" which has an Aldames equivalent of "LL/ll" or "LY/ly." However, the letters "Q/q" which can be translated on how the letter is articulated as "KYU/kyu" with an Aldames equivalent of "NYU/nyu" and "X/x" which can be translated into "EKS/eks" with an Aldames equivalent of "ENT/ent."

Table 2. Comparison between the Cebuano and Aldames languages as used by the Speakers

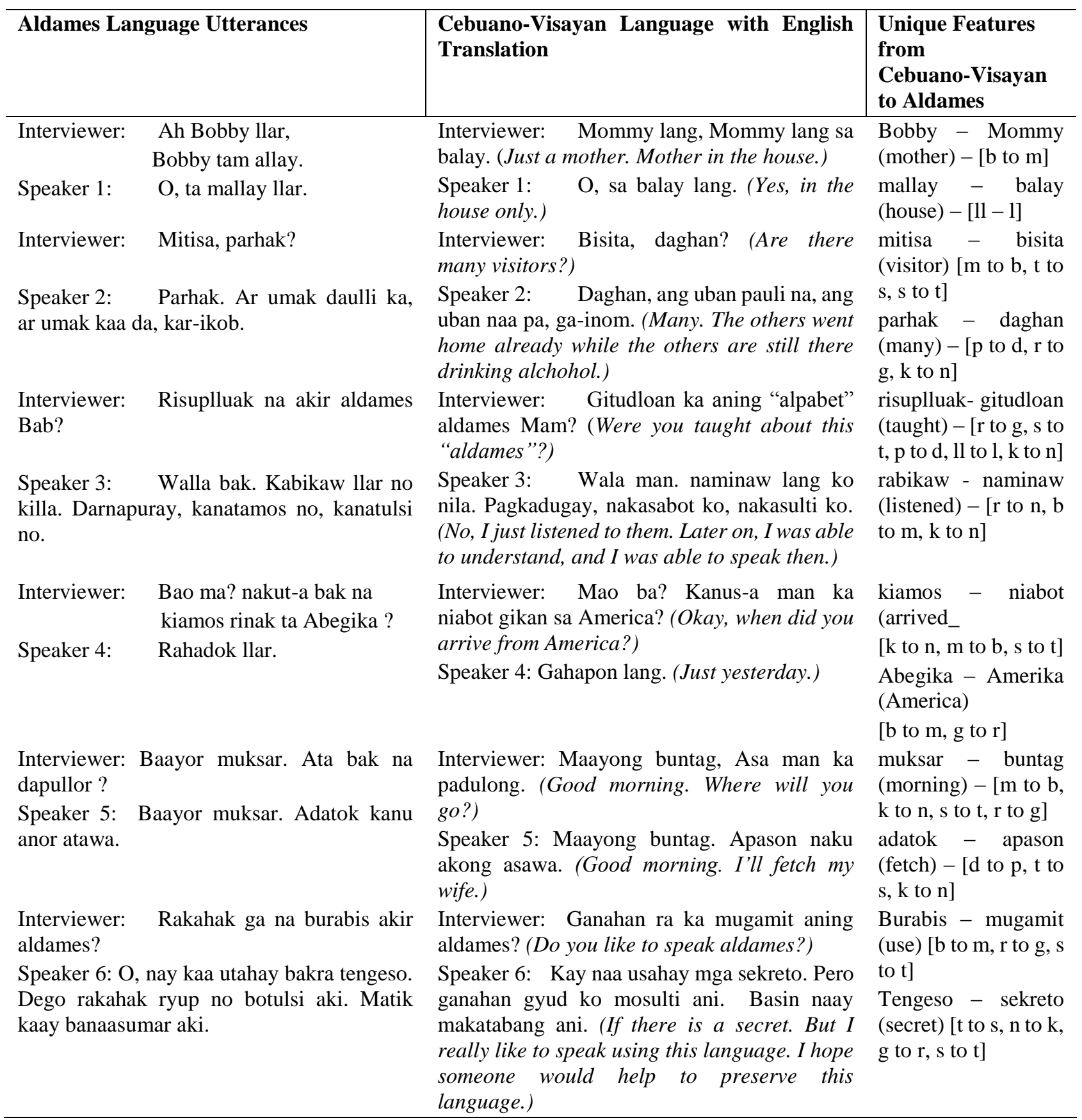




\subsection{Challenges in Speaking Cebuano-Visayan and Aldames Languages}

The most challenging part of every speaker of a certain language is to shift from one language to the other because it generally depends on the flow of the discussion. Sometimes, the flow of communication would resort to codeswitching. However, the speakers of the Aldames language did not have any problem in shifting from Cebuano-Visayan to Aldames. The respondents were asked whether it would be challenging for them to shift from "Aldames" to "Cebuano-Visayan" or vice versa. They responded that:

Speaker 1: $\quad$ Pilli ga bak dop, palli ga bak bamalhik rinak aldames payok Temuako. (I can easily shift to Cebuano even if I previously communicate in aldames.)

Speaker 2: $\quad$ Pilli ga bak dop, palli ga bak bamalhik rinak aldames payok Temuako. (No, I can easily shift from Aldames to Cebuano.)

Speaker 3: Baayo uksa pilli bababsay niking aldames. Pano niki ur rabis ryop. Ta ano llar dakak-aw. (At my age, I am used to it. It is easy for me to shift from Cebuano to Aldames.)

Speaker 4: Pilli ga uy. Palli ga bak rup ka i-Temuako rinak ta aldames. Kaakap ka bak rud ko. (No. I can easily shift to Cebuano. I am used to it.)

Speaker 5: Tire ka bak no natullay aka, Palli ga bak basumar ar etsogya kra Temuako mitak rinak no kar aldames. (I have been used that. I can easily respond and communicate in Cebuano even if I had just talked in aldames.)

Speaker 6: Walla gay dogobllega. Palli ga bamalhik rinak ta aldames agok ba Temuano. (It's not a problem. It is easy to shift from aldames to Cebuano.)

These were the responses of the respondents on the question about shifting from Cebuano to Aldames or Aldames to Cebuano-Visayan. All of them responded that shifting from Cebuano-Visayan to Aldames was not a problem because they are used to both languages since childhood. Considering that they are familiar and fluent with both languages (Cebuano-Visayan and Aldames), so shifting from one language to the other is just easy for all speakers. In other words, codeswitching is impossible if one speaker speaks the Aldames language because all features (especially on the consonants) in the Cebuano-Visayan language have corresponding unique features in the Aldames language.

\subsection{Preservation of the Language}

The speaker-participants of the study recommended that the language has been in existence since they were still a child, and the usage of Aldames language does not affect their speaking of the Cebuano-Visayan language. They even could not codeswitch in speaking the Aldames language compared to the Cebuano-Visayan language; hence, they highly recommended to preserve the language by adding the Aldames language as an official one and to be considered as one of the many languages and dialects in the Philippines. Speaker 3 emphasized that: "Baayo uksa pilli bababsay niking aldames. Pano niki ur rabis ryop. Ta ano llar dakak-aw." (I am hoping that this will be preserved. This "aldames" has helped a lot in my opinion.). All the speakers agreed to preserve the Aldames language because they find it distinct and unique as a Filipino who are known to be multilingual speakers. They suggested to include a learning material specialized to the learners of Bato, Samboan, Cebu, Philippines and to integrate the said material to the Mother Tongue-Based Multilingual Education (MTB-MLE) curriculum of the Enhanced Basic Education Act of 2013 otherwise known as the Republic Act 10533 (Gazette, 2013).

\section{Discussion}

There is no specific person to explain the origin or roots of the Aldames language, so identifying the speakers of the Aldames language would help in determining the duration of the said language. It has been said that the speakers who passed away also used the Aldames language since birth, and thus, it could be understood that Aldames language existed over a century. Some learned from their parents while others from their grandparents, friends, and relatives or even colleagues. Based on the profile of the speakers, it is evident that the majority of the Aldames speakers learned the language between family members living in the same roof because the Philippines is known for its nuclear family even if their children have their own families, they are still allowed to live in the same house. This was clearly illustrated in the profiles of the speakers. 
As to the characteristics of the language, it was found out that the "Aldames" language is a modified version of the English alphabet because the language has corresponding letters in English. However, changes occur in most consonants (b/v-m, c/k-n, d-p, f.p-d, g/ng-r, k/c-n, 1-ll/ly, m-b, n-k/c, p-d, q/kyu-nyu, r-g/ng, s-t, y/eks-ent, z/s-t) while all vowels $(\mathrm{a}, \mathrm{e}, \mathrm{i}, \mathrm{o}, \mathrm{u})$ and few consonants $(\mathrm{h}, \mathrm{w}$, and $\mathrm{y})$ are retained. There is no equivalent for the $\mathrm{J} / \mathrm{j}$ letter, and there is no proper or common noun in the Aldames language because it simply translates into its corresponding letter-substitute. The sounds or consonant stops in English phonemes are not significant because each consonant in the Cebuano-Visayan language has a corresponding letter in the Aldames language. However, another unique feature in the Aldames language is that even though it is just a mere change or substitute of consonants, the fluency of the speakers in switching from a certain language to another is only common to Cebuano-Visayan to Aldames or vice versa. The mere substitute could be applied to any languages that use the English alphabet, but the familiarity and fluency of the Aldames language speakers is originally anchored on the Cebuano-Visayan language being the first language (L1) of the speakers.

The speaker of Aldames language are native Cebuano-Visayan speakers, and they are fluent of the Cebuano-Visayan language (L1). There is even no implication that a speaker knows how to speak the Aldames language because codeswitching from Cebuano-Visayan to Aldames is not evident from the speakers as they speak the first language. Also, it was found out that the speakers are quick enough to shift from Cebuano-Visayan language to Aldames because they were not having any difficulty in shifting from Aldames to Cebuano-Visayan or vice versa. Since the speakers were already familiar of the first language and the equivalent terms in the Aldames, the shifting from Cebuano-Visayan to Aldames or from Aldames to Cebuano-Visayan was not an issue/problem for them.

With the Aldames language being spoken in Bato, Samboan, Cebu residents, the Aldames speakers strongly recommended the proper documentation of the language, and they wanted that the language has to be included in the list of languages and dialects spoken in the Philippines. Presently, the language is not only spoken in Bato, Samboan, Cebu residents, but also to the residents of the neighboring barangays.

\section{Conclusion and Recommendation}

The speakers' age determined the estimated period of existence of the Aldames language most especially the two (2) speakers who passed away at the age of 95 and 96, respectively, for over a decade ago (since 2017). The period when the Aldames language originated was very significant to the speakers because most of the living speakers were influenced from their grandparents and parents. It generally started from their respective households as a language to hide secrets to the younger generations who were not yet familiar with the Aldames language. It was then carried on as a part of their daily language with the first language (Cebuano-Visayan). Aldames language is characterized by its unique features especially most of the consonants were substituted with a corresponding letter from the English alphabet except for the vowels and a few consonants which were retained from their original features. Also, the speakers were familiar and fluent only in shifting Cebuano-Visayan to Aldames though Aldames language could be applied in any other languages using the English alphabet as the basis. The speakers did not have problems or difficulties in shifting from the first language (Cebuano-Visayan) to Aldames because they were already familiar with the terms of both languages.

Therefore, Aldames language is a unique language, and considering that there are fluent speakers of the language, it is still preserved until today but only to a number of speakers. The version of the Aldames language is not common because most of the languages when they vary, the variation is more on the lexicon; however, in the Aldames language, it is more on letters. There are letters which have the same Aldames equivalent while some are on the sounds. Also, it is different from other languages because once a speaker uses the language, he/she says the language purely without codeswitching. Considering that the language is still used by the community in Bato, Samboan, Cebu, Philippines, and now slowly spreading to its neighboring places, it is recommended that there is a proper documentation of the language especially on its unique features. Also, a dictionary of terms may be developed to help non-speakers be aware of the existence of the language, for it will have a bigger coverage once the dictionary is published.

\section{Acknowledgments}

The authors would like to express their heartfelt gratitude to the participants-speakers especially to Maria "Mary" Ferrater-Singco, the oldest living speaker, who had been very supportive and cooperative from the very start up to the completion of this work. 


\section{References}

Bernas, J. G. (1996). The 1987 constitution of the Republic of the Philippines: A commentary. Rex Bookstore, Inc.

Bisaya.Com. Dictionary ug Uban pa, Retrieved on September 10, 2017 from www.bisaya.org

Endriga, D. A. P. (2010). The Dialectology of Cebuano: Bohol, Cebu and Davao. In 1st MLE Conference, "Reclaiming the Right to Learn in One's Own Language (pp. 18-20).

Gazette, O. (2013). Republic Act No. 10533 of the Republic of the Philippines.

Hall, Shane. Grants for research on endangered languages. eHow.com http://www.ehow.com/info_7903500_grants-research-endangeredlanguages.html\#ixzz26pVPFE00 September $18,2017$.

Major languages of the Philippines. Retrieved on September 10, 2017 from http://www.csun.edu/ lan56728/majorlanguages.htm

Microsoft Encarta Premium (2009). The world's endangered languages. September 15, 2017

National Geographic http://travel.nationalgeographic.com/travel/enduring-voices/ September 15, 2017.

Philippines History Index. (2001). Retrieved on September 3, 2017 from http://workmall.com/wfb2001/philippines/philippines_history_index.html

Scott, J. (2011). What languages are spoken in the Philippines. Retrieved on September 1, 2017 From http://translation-blog.trustedtranslations.com/what-languages-are-spoken-in-the-philippines-2011-05-29.html

Steinberg, D. J. (1982). The Philippines: A Singular and A Plural Place. Boulder: Westview Press

Warford, M. (2011). Narrative language pedagogy and the stabilization of Indigenous languages. Vol. 11, No. 1. Bufalo State College, The Reading Matrix. http://www.readingmatrix.com/articles/january_2011/warford.pdf September 18, 2012

\section{APPENDICES}

\section{A. INTERVIEWS}

\section{SPEAKER 1}

\section{Aldames Language}

Interviewer: Nubutsa bak na nagok? Ruada naayo na.

Speaker 1: $\quad$ Baayo, baayo ga. Tallabas.

Interviewer: Ruada rihadok na.

Speaker 1: Inaw dop, inaw dop,

Interviewer: Haik bak na karduyo nagok?

Speaker 1: Kaa ka no karduyo ta Makawa nagok.

Interviewer: Ah, Makawa ta tyupap.

Speaker 1: $\quad$ O, ta tyupap ta Temu.

Interviewer: Dilla ban namuon ibo akan?

Speaker 1: $\quad$ Uta llar, lallani.

Interviewer: Lallani, lliwas dada, ruado.

Speaker 1: Lliwas dada ur baba.

Interviewer: Daulli na nagok ta tyupap?

Speaker 1: Daulli no ukya nay kaay nallate anor masa.

Interviewer: Kaa dop na sagamaho.

Speaker 1: Walla ka no karsagamaho.

Interviewer: Ah Bobby llar, Bobby tam allay. 
Speaker 1: O, ta mallay llar.

Interviewer: Asa bak na kananas-ok akir aldames?

Speaker 1: $\quad$ Ta bakra sawo ta abor mallay ur ta bakra tillikrak. Bakra abira dop.

Interviewer: Nok kaay bakrusaka kibo ur Temuako ukya kaa nay naetsogya ta aldames, pilli ga na barllitop bosumar ur Temuako dop?

Speaker 1: $\quad$ Banasumar ga bak no payok ur Temuako rinak no ra aldames.

Interviewer: Lyek, tallabas ryop naayo ta ibor dakahok kra anor ritabon.

Speaker 1: $\quad$ Tallabas dop.

\section{Cebuano-Visayan Version (English Version)}

Interviewer: Kumusta na man ka karon? Guapa kayo ka. (Len, how are you now? You are very beautiful.)

Speaker 1: $\quad$ Maayo, mayo ra. Salamat. (Fine, I'm fine. Thank you.)

Interviewer: Guapa gihapon ka. (You are still beautiful.)

Speaker 1: $\quad$ Ikaw pod, ikaw pod. (You, too. You, too.)

Interviewer: Hain man ka nagpuyo karon? (Where do live now?)

Speaker 1: $\quad$ Naa na ko nagpuyo sa Banawa karon. (I'm living in Banawa now.)

Interviewer: Ah, Banawa sa syudad? (Ah, Banawa in the city?)

Speaker 1: $\quad$ O, sa syudad sa Cebu. (Yes, in the city of Cebu.)

Interviewer: Pila man kabuok imo anak? (How many children do you have?)

Speaker 1: $\quad$ Usa lang, lalaki. (Only one, a boy.)

Interviewer: Lalaki, liwat sa papa, guapo. (A boy, just like the father, handsome, too.)

Speaker 1: $\quad$ Liwat sa papa ug mama. (Like the father and the mother.)

Interviewer: Pauli ka karon sa syudad? (Are you going home now in the city?)

Speaker 1: $\quad$ Pauli ko unya kay nay klase akong bata. (I'll be going home late because my son has a class.)

Interviewer: Naa pod ka trabaho? (Do you also have a job?)

Speaker 1: Wala na ko nagtrabaho. (I didn't anymore work.)

Interviewer: Mommy lang, Mommy lang sa balay. (Just a mother. Mother in the house.)

Speaker 1: $\quad \mathrm{O}$, sa balay lang. (Yes, in the house only.)

Interviewer: Asa man ka nakakat-on aning aldames? (Len, where did you learn to speak aldames?)

Speaker 1: Sa mga tawo sa among balay ug sa among silingan. Mga amiga pod. (From the people in the house and from my neighbors. From my friends, too.)

Interviewer: Kon naay mangutana nimo ug Cebuano unya naa kay kaestorya sa aldames dili ra ka Maglisod motubag ug Cebuano pod? (If there's somebody who would ask you in Cebuano, and there's somebody who would also communicate in aldames, are you not having a hard time shifting from one language to another?)

Speaker 1: Makatubag ra man ko dayon ko ug Cebuano gikan ko ga aldames. (I can easily shift to Cebuano even if I previously communicate in aldames.)

Interviewer: Salamat kaayo sa imong panahon nga akong gikuha. (Thank you so much for the time that I got from you.)

Speaker 1: $\quad$ Salamat pod. (Thank you, too.) 


\section{SPEAKER 2}

\section{Aldames Version}

Interviewer: Pahl, baayor hadok piha,

Speaker 2: $\quad$ Baayor hadk bakar.

Interviewer: Ditsa bak piay nagok. Parhak sawo?

Speaker 2: $\quad$ Parhak dop.

Interviewer: Ukya, kaa gay banaok?

Speaker 2: $\quad$ Kaa, parhak, puha bak na llistok.

Interviewer: Tup-ak, parhak?

Speaker 2: Parhak.

Interviewer: Mitisa, parhak?

Speaker 2: $\quad$ Parhak. Ar umak daulli ka, ar umak kaa da, kar-ikob.

Interviewer: Ukta bay umar banaok?

Speaker 2: $\quad$ Llistok, itpa, sugsa, nonit, ur umak da.

Interviewer: Barpallya ukya no.

Speaker 2: $\quad$ Saraak na kano.

Interviewer: Ay,ta pilli da no ballibos, piik piay na nanas-ok akir aldames?

Speaker 2: $\quad$ Ta aboa ga payok ta bakra naumak ta sagamaho.

Interviewer: Nok kaay bakrusaka kibo ur Temuako ukya kaa nay naetsogya ta aldames, pilli ga na barllitop bosumar ur Temuako dop?

Speaker 2: $\quad$ Pilli ga bak dop, palli ga bak bamalhik rinak aldames payok Temuako.

Interviewer: Tallabas ha. Pilli bi barpuray nay hadok ka naayo.

Speaker 2: Wallay tadayak.

\section{Cebuano-Visayan Version (English Version)}

Interviewer: Dahl, maayong hapon diha. (Dahl, good afternoon.)

Speaker 2: $\quad$ Maayong hapon Manang. (Good afternoon, "Manang.")

Interviewer: Pista man diay karon, daghan tawo? (Today is a feast day, many people.)

Speaker 2: $\quad$ Daghan pod. (Many, too.)

Interviewer: Unya naa ray makaon? (Then, do you have food prepared.)

Speaker 2: $\quad$ Naa, daghan, duha man ka litson. (I have. There are two roasted pigs.)

Interviewer: Sud-an, daghan? (Are there many dishes?)

Speaker 2: Daghan. (Many.)

Interviewer: Kan-on? (Rice?)

Speaker 2: Daghan. (Many.)

Interviewer: Bisita, daghan? (Are there many visitors?)

Speaker 2: Daghan, ang uban pauli na, ang uban naa pa, ga-inom. (Many. The others went home already while the others are still there drinking alchohol.) 
Interviewer: Unsa may ubang makaon? (What are other food you prepared?)

Speaker 2: $\quad$ Litson, isda, turta, cookies, ug uban pa. (Roasted pig, fish, cake, cookies, and many others.)

Interviewer: Magdala unya ko. (Can I bring some?)

Speaker 2: $\quad$ Tagaan ka nako. (Yes, I'll give you.)

Interviewer: Ay, sa dili pa ko malimot, diin diay ka kakat-on aning aldames? (Ah, before I forget, where did you learn aldames?)

Speaker 2: $\quad$ Sa amoa ra dayon sa mga kauban sa trabaho. (From our house and from my colleagues.)

Interviewer: Kon naay mangutana nimo ug Cebuano unya naa kay kaestorya sa aldames dili ra

ka Maglisod motubag ug Cebuano pod? (If there's somebody who would communicate you in Cebuano, and you are also talking to someone in aldames, are not having a hard time responding in Cebuano?)

Speaker 2: $\quad$ Dili ra man pod, dali ra man mabalhin gikan aldames dayon Cebuano. (No, I can easily shift from Aldames to Cebuano.)

Interviewer: Salamat ha ... dili mi magdugay kay hapon na kaayo. (Thank you so much...I will not stay any longer because it's already late in the afternoon.)

Speaker 2: $\quad$ Walay sapayan. (You're welcome)

\section{SPEAKER 3}

\section{Aldames Version}

Interviewer: Baayor muksar Bab.

Speaker 3: $\quad$ Baayor muksar dop.

Interviewer: Puray ka nuko na nahimallo botulsi akir 'aldames'.

Speaker 3: $\quad$ O, masa da no, dullo na suir, kan pukror no tau mar epap-epagak akir "aldames."

Interviewer: Ukta piay ki siya Bab?

Speaker 3: $\quad$ Tauka, illa ki rirabis agok pilli banatamos ar bara masa nok kaay etsogyahak kra daga bara sirulllar.

Interviewer: Risuplluak na akir aldames Bab?

Speaker 3: $\quad$ Walla bak. Kabikaw llar no killa. Darnapuray, kanatamos no, kanatulsi no.

Interviewer: Ibor sak-aw, parhak da ar kar rabis o tulsi aki nagok?

Speaker 3: $\quad$ O, anor bara akan, anor umak kra bara ado, anor abira ur abiro ur dagyekse.

Interviewer: Ukta bay ibor inatulsi aki daga nagok?

Speaker 3: $\quad$ Baayo uksa pilli bababsay niking aldames. Pano niki ur rabis ryop. Ta ano llar dakak-aw.

Interviewer: Misaw Bab, baayo dop. Ay Bab, tallabas naayo ta ibor samar.

Speaker 3: Wallay tadayak.

\section{Cebuano-Visayan Version (English Version)}

Interviewer: Maayong buntag Mam. (Good morning, Ma'am.)

Speaker 3: $\quad$ Maayong buntag pod. (Good morning, too.)

Interviewer: Dugay na kuno ka nakahibalong mosulti aning "alpabet” aldames. (I have learned that you have been speaking this "Aldames" a long time ago.)

Speaker 3: $\quad$ O, bata pa ko, pulo ka tuig, nakadungog ko sa ubang edad-edaran aning 
"alphabet" aldames. (Yes, when I was still a child, 10 years old, I heard the elders are speaking “aldames.”)

Interviewer: Unsa diay ni siya Mam? (What is this Ma'am?)

Speaker 3: $\quad$ Sa una ila ni gigamit aron dili makasabot ang mga bata kon nay estoryahan nga para sa mga tigulang. (Before, they were using this, so the children would not be able to understand what the elders were talking about.)

Interviewer: Gitudloan ka aning "alpabet” aldames Mam? (Were you taught about this "aldames”?)

Speaker 3: $\quad$ Wala man. naminaw lang ko nila. Pagkadugay, nakasabot ko, nakasulti ko. (No, I just listened to them. Later on, I was able to understand, and I was able to speak then.)

Interviewer: Sa imong tan-aw daghan pa ang nag gamit o sulti ani karon? (In your opinion, are there still people who are using or speaking this language now?

Speaker 3: $\quad$ O, akong mga anak, akong mga apo, akong mga amiga ug amigo ug paryente. (Yes, my children, my grandchildren, my friends, and my relatives.)

Interviewer: Unsa may imong ikasulti ani para karon? (What can you say about this language now?)

Speaker 3: $\quad$ Maayo unta dili mamatay kining "alphabet” aldames, dako kini ug gamit gyod.

Sa ako lang panan-aw. (I am hoping that this will be preserved. This "aldames"

has helped a lot in my opinion.)

Interviewer: Kon naay mangutana nimo ug Cebuano unya naa kay kaestorya sa aldames dili ra

ka Maglisod motubag ug Cebuano pod? (If there's somebody who would ask you in Cebuano, and you are communicating to another person in aldames, don't you have any difficulty in talking to Cebuano?)

Speaker 3: $\quad$ O sa akong edad medyo naanad na gyud ko ana. Dali ra man ibalhin ug sinibuano, kon gikan nagestorya ug aldames. (At my age, I am used to it. It is easy for me to shift from Cebuano to Aldames.)

Interviewer: Bitaw Mam, maayo pod. Ay Mam, salamat kaayo sa imong tabang. (Yes, I agree. It is better, too. By the way, Ma'am, thank you so much for your help.)

Speaker 3: $\quad$ Walay sapayan. (You're welcome.)

\section{SPEAKER 4}

\section{Aldames Version}

Interviewer: Nubutsa, kia llari na.

Speaker 4: $\quad$ O, kidaulli no nay kabasay ban ano aduhak.

Interviewer: Bao ma? nakut-a bak na kiamos rinak ta Abegika?

Speaker 4: Rahadok llar.

Interviewer: Baayo nay kanahimallo da na etsogya ur aldames.

Speaker 4: $\quad$ Bao ryup. Piha maya no nahimallo aldames akar ador aduhak kra kabasay.

Interviewer: Risuplluak na akar aldames ?

Speaker 4: Walla, nay bahapllon bak ar sirullar kra batamsak ta bakra masa.

Interviewer: Nok kaay bakrusaka kibo ur Temuako ukya kaa nay naetsogya ta aldames, pilli ga na barllitop bosumar ur Temuako dop?

Speaker 4: $\quad$ Pilli ga uy. Palli ga bak rup ka i-Temuako rinak ta aldames. Kaakap ka bak rud ko. 
Interviewer: Misaw ryup. Tire tallabas ..... Nokpollekt.....

\section{Cebuano-Visayan Version (English Version)}

Interviewer: Kumusta nia lagi ka. (How are you? Why are you here?)

Speaker 4: $\quad$ O, nipauli ko kay namatay man ako apuhan. (Yes, I come home because my grandmother passed away.)

Interviewer: Mao ba? Kanus-a man ka niabot gikan sa America? (Okay, when did you arrive from America?)

Speaker 4: $\quad$ Gahapon lang. (Just yesterday.)

Interviewer: Maayo kay nakahibalo pa ka estorya ug aldames. (Good that you know how to speak aldames.)

Speaker 4: $\quad$ Mao gyud. Diha baya ko kahibalo aldames anang akong apuhan nga namatay. (Yes, you're correct. I learned to speak aldames from my grandmother who passed away.)

Interviewer: Gitudluan ka anang aldames? (Were you taught how to speak aldames?)

Speaker 4: Wala, kay mahadlok man ang tigulang nga masabtan sa mga bata. (No, because the elders were afraid to be understood by the children.)

Interviewer: Kon naay mangutana nimo ug Cebuano unya naa kay kaestorya sa aldames dili ra ka Maglisod motubag ug Cebuano pod? (If there's somebody who would ask you

in Cebuano, and it happened that you are also talking to someone in aldames, are you not having any difficulty in responding to Cebuano?

Speaker 4: Dili ra uy, dali ra man gud na i-Cebuano. Naanad na ko. (No. I can easily shift to Cebuano. I am used to it.)

Interviewer: Bitaw gyud. Sige salamat..... Condolence (Kondolens) (Yes, you're correct. Thank you....my condolences.)

\section{SPEAKER 5}

\section{Aldames Version}

Interviewer: Baayor muksar Speaker 5. Ata bak na dapullor ?

Speaker 5: Baayor muksar. Adatok kanu anor atawa.

Interviewer: Piik bak na nanas-ok akir aldames ?

Speaker 5: $\quad$ Ta anor baba ur dada ur anor aduhak .

Interviewer: Tige bo rabis akir aldames ta ikyo?

Speaker 5: $\quad$ O, baayo bak boetsogya anor aduhak. Utahay pilli banatamos anor barhup. Suplluak ta anor aduhak.

Interviewer: Rakahak ga na akir tikulsiaka ?

Speaker 5: O, tire bak dop kabo rabisok ta mallay.

Interviewer: Kaay bakrusaka kibo ur Temuako ukya kaa nay naetsogya ta aldames, pilli ga na barllitop bosumar ur Temuako dop?

Speaker 5: Tire ka bak no natullay aka, Palli ga bak basumar ar etsogya kra Temuako mitak rinak no kar aldames.

Interviewer: Tallabas ha... Datektya ta pitsugmo. 


\section{Cebuano-Visayan Version (English Version)}

Interviewer: Maayong buntag, Asa man ka padulong. (Good morning. Where will you go?)

Speaker 5: $\quad$ Maayong buntag. Apason naku akong asawa. (Good morning. I'll fetch my wife.)

Interviewer: Diin man ka kakat-on aning aldames? (Where did you learn aldames?)

Speaker 5: $\quad$ Sa akong mama ug papa ug apuhan. (From my mother and my father and grandmother.)

Interviewer: Sige mo gamit aning aldames sa inyo? (Are you always using aldames at home?)

Speaker 5: O, mayo man moestorya akong apuhan. Usahay dili makasabot akong manghud.

Tudluan sa akong apuhan. (Yes, because my grandmother is fluent in speaking aldames. Sometimes, my younger sister does not understand, so my grandmother teaches her.)

Interviewer: Ganahan ra ka aning sinultiana? (Do you like the language?)

Speaker 5: $\quad$ O, sige man pod namo gamiton sa balay. (Yes, because we always use this at home.)

Interviewer: Kon naay mangutana nimo ug Cebuano unya naa kay kaestorya sa aldames dili ra ka Maglisod motubag ug Cebuano pod? (If there's somebody would ask you in

Cebuano, and it happened that you are also talking to somebody in aldames, are you not having a hard time responding in Cebuano?)

Speaker 5: $\quad$ Sige na man ko kasulay ana. Dali ra man matubag ang estorya nga Cebuano bisan gikan ko nag aldames. (I have been used that. I can easily respond and communicate in Cebuano even if I had just talked in aldames.)

Interviewer: Salamat ha. Pasensya sa disturbo. (Thank you. I am sorry for the disturbance.)

\section{SPEAKER 6}

\section{Aldames Version}

Interviewer: Baayo nay karnisa sa.

Speaker 6: Krako bak piay?

Interviewer: Kahimallo bak no kra baayo na akir aldames. Puray ka na kar-etsogya aki ?

Speaker 6: $\quad$ Puray ka oy. Masa da no banatulsi ka no ur rabay kra aldames.

Interviewer: Nikta bay karsupllo kibo?

Speaker 6: Umak anor baba, utahay anor aduhak. Dego kananas-ok dop no ta bakra abira kanu.

Interviewer: Rakahak ga na burabis akir aldames?

Speaker 6: O, nay kaa utahay bakra tengeso. Dego rakahak ryup no botulsi aki. Matik kaay banaasumar aki.

Interviewer: Kaay bakrusaka kibo ur Temuako ukya kaa nay naetsogya ta aldames, pilli ga na barllitop bosumar ur Temuako dop?

Speaker 6: Walla gay dogobllega. Palli ga bamalhik rinak ta aldames agok ba Temuano

Interviewer: Misaw ryup. Tallabas Speaker 6 ha.

\section{Cebuano-Visayan Version (English Version)}

Interviewer: Maayo kay nagkita ta. (Good that we have met.)

Speaker 6: $\quad$ Ngano man daiy? (Why?)

Interviewer: Nahibalo man ko nga maayo ka aning aldames. Dugay na kanag-westorya ani? (I 
know that you are very fluent in speaking aldames. How long have you been speaking the language?)

Speaker 6: Dugay na oy. Bata pa ko makasulti na ko ug gamay nga aldames. (Long time ago.

When I was still a child, I used to speak the aldames a little.)

Interviewer: Kinsa may nagtudlo nimo? (Who taught you this?)

Speaker 6: $\quad$ Uban akong mama, usahay akong apuhan. Pero nakakat-on pod ko sa mga amiga naku. (Some from my mother, some from my grandparents. But I also learned from my friends.)

Interviewer: Ganahan ra ka mugamit aning aldames? (Do you like to speak aldames?)

Speaker 6: $\quad$ Kay naa usahay mga sekreto. Pero ganahan gyud ko mosulti ani. Basin naay

makaatabang ani. (If there is a secret. But I really like to speak using this language. I hope someone would help to preserve this language.)

Interviewer: Kon naay mangutana nimo ug Cebuano unya naa kay kaestorya sa aldames dili ra ka Maglisod motubag ug Cebuano pod? (If there's somebody who would ask you in Cebuano, and it happened that you are also talking to someone in aldames, are you not having any difficulty in shifting to Cebuano?)

Speaker: $\quad$ Wala ra nay problema. Dali ra mabalhin gikan sa aldames aron ma Cebuano. (It's not a problem. It is easy to shift from aldames to Cebuano.)

Interviewer: $\quad$ Bitaw gyud. Salamat Sing ha. (Yes, I agree speaker 6).

\section{B. LIST OF CEBUANO-VISAYAN WORDS with ALDAMES AND ENGLISH TRANSLATION}

\begin{tabular}{|c|c|c|}
\hline $\begin{array}{l}\text { Common Dialect } \\
\text { (Cebuano) }\end{array}$ & Aldames & English \\
\hline ato & asò & our \\
\hline bata & masa & child \\
\hline baka & mana & cow \\
\hline saging & tarir & banana \\
\hline gikapoy & rinadoy & tired \\
\hline buhok & muhon & hair \\
\hline mama & baba & mom/mother \\
\hline saba & tama & noisy \\
\hline pan & Dak & bread \\
\hline balay & mallay/ malyay & house \\
\hline bulad & mullap/ mulyap & dried fish \\
\hline itlog & isllor/ islyor & egg \\
\hline manok & bakon & chicken \\
\hline pisò & ditò & chick \\
\hline iro & igo & $\operatorname{dog}$ \\
\hline kanding & nakpir & goat \\
\hline inahan & ikahak & mother \\
\hline amahan & abahak & father \\
\hline anak & akan & son/daughter \\
\hline bodbod & mopmop & suman \\
\hline
\end{tabular}




\begin{tabular}{|c|c|c|}
\hline dyes/diyes & pyet/piyet & ten \\
\hline puti & dusi & white \\
\hline bayad & mayap & pay \\
\hline isda & itpa & fish \\
\hline utan & usak & vegtable soup \\
\hline sud-an & tup-ak & viand \\
\hline tulog & sullor/ sulyor & sleep \\
\hline gitulog & risullor/ risulyor & sleepy \\
\hline maligo & balliro/ balyiro & take a bath \\
\hline paniudto & dakiupso & lunch \\
\hline erpari & dagi & priest \\
\hline maestra & baetga & female teacher \\
\hline busog & mutor & full/satisfied \\
\hline motor & bosog & motorcyle \\
\hline talong & Sallor/salyor & eggplant \\
\hline lubi & llumi/lyumi & coconut \\
\hline mangga & bakra & mango \\
\hline sabaw & tamaw & soup \\
\hline humay & hubay & rice \\
\hline sinina & tikika & dress \\
\hline kawayan & nawayak & bamboo \\
\hline bakak & manan & lie \\
\hline $\operatorname{tanan}$ & sakak & all \\
\hline sapatos & tadasot & shoes \\
\hline sabot & tamos & understand \\
\hline bati & masi & ugly \\
\hline paypay & dayday & fan \\
\hline tapulan & sadullak/sadulyak & lazy \\
\hline palit & dallis/dalyis & buy \\
\hline sweldo & twelpo & salary \\
\hline bag-o & mar-o & new \\
\hline tan-aw TV ( tivi) & sak-aw SiMi & watch TV \\
\hline bukid & munip & mountain \\
\hline dalô & pallo/ palyo & Selfish/greedy \\
\hline tabian & samiak & talkative \\
\hline guapa & ruada & pretty \\
\hline guapo & ruado & handsome \\
\hline taas & saat & tall \\
\hline tambok & sabmon & fat \\
\hline sabon & tamok & soap \\
\hline
\end{tabular}




\begin{tabular}{|l|l|l|}
\hline gatas & rasat & milk \\
\hline bug-at & mur-as & heavy \\
\hline gaan & raak & light \\
\hline daku & panu & big \\
\hline gamay & rabay & small \\
\hline niwang & kiwar & thin/ skinny \\
\hline akô & anô & mine \\
\hline salamat & tallabas/talyabas & thank you \\
\hline
\end{tabular}

\section{LIST OF COMMON EXPRESSIONS/QUERIES}

\begin{tabular}{|l|l|l|}
\hline CEBUANO & ALDAMES & ENGLISH \\
\hline Maayong buntag. & Baayor muksar. & Good morning. \\
\hline Kumusta ka? & Nubutsa na? & How are you? \\
\hline Guapa siya. & Ruada tiya. & She is pretty/beautiful. \\
\hline Nikaon na ka? & Kinaok ka na? & Have you eaten already? \\
\hline Nasuko ko. & Natuno no. & I am angry. \\
\hline Nalipay siya. & Kalliday/kalyiday tiya. & He/she is happy. \\
\hline
\end{tabular}

English words can be translated to the "Aldames" language.

Examples:

1. Don't-Pok's

2. Love (lav) - Llyam / Lyam

3. Wait (weyt) for me- weys dog be 